\title{
STUDIES ON THE CIRRIPEDIAN FAUNA OF JAPAN. -VI. CIRRIPEDS FROM KYUSYU AND RYUKYU ISLANDS-
}

\author{
$\operatorname{AUTHOR}(S):$
}

Utinomi, Huzio

\section{CITATION:}

Utinomi, Huzio. STUDIES ON THE CIRRIPEDIAN FAUNA OF JAPAN. -VI. CIRRIPEDS FROM KYUSYU AND RYUKYU ISLANDS-. PUBLICATIONS OF THE SETO MARINE BIOLOGICAL LABORATORY 1949, 1(2): 19-37

\section{ISSUE DATE:}

1949-12-25

URL:

http://hdl.handle.net/2433/174435

RIGHT: 


\title{
STUDIE; ON THE CIRRIPEDIAN FAUNA OF JAPAN \\ VI. CIRRIPEDS FROM KYUSYU
}

AND RYUKYU ISLANDS*

\author{
Huzio UTINOMI* \\ With 6 Text-figures \\ Introduction
}

Our knowledge of the cirripedian fauna of the Kyusyu and Ryukyu Islands has been rather meagre and limited largely to ceepwater forms. The littoral or intertidal forms have never been investigated. On two occasions of my visit to Kyusyu and neighbouring islands in 1936 and 1943, I collected littoral cirripeds at several places. I also examined collections of the same group stored in various museums and institutes in these districts.

The material dealt with in the present paper consists largely of the specimens obtained during these collecting trips, as well as those collected by the members of the Zoological Institute in the Kyusyu University and of the Amakusa Marine Biological Station on various occasions. Besides, by kindness of my friend biologists a number of specimens coming from the localities in those districts were entrusted to me for study. I wish to express my appreciation to these gentlemen and also to the Japan Society for the Promotion of Scientific Research for its financial aid in carrying out this work.

The following list gives the names of the species included in the present report together with their localities (those marked with an asterisk* are commented upon in detail in the systematic account):

Family Scalpellidae PILSBRY

* Contributions from the Seto Marine Biological Laboratory, No. 123.

** The author's name was formerly Fujio HrRo.

Publ. Seto Mar. Biol. Lab., I (2) 1949. 
1. Mitella mitella (LINNÉ:

Kyusyu : Mozi; Hakata Bay, Hukuoka-ken (mihi '39). Okinosima; Korea Strait OHshima '33). Tomioka, Amakusa Is.; Ibusuki, Iso, Kekura, Kagosima-ken (UTUNo '33). Yakusima and Tanegasima (TOKuDA and NAKamura '33; mihi '43). Ryukyu: Yaéyama Is. (IWAsakI).

2. Calantica scorpio (Aurrvillius)

Tomioka, Amakusa Is., on a hydroid Dendrocoryne sp. (HABE '42).

\section{Family Tolidae (LEACH) ANNANDALE}

3. Ibla cumingi DARWIN

Tomioka, Amakusa Is. (Baba'38; mini'43).

\section{Family Oxynaspidae NILSSON-CANTELL}

4. Oxynaspis paoifica HiRo

Tomioka, Amakusa Is., on an antipatharian (TKEDA '31; BABA '33).

Family Lepadidae (DARWIN) NILSSON-CANTELL

5. Lepas anatifera LINNÉ

Okinosima, Korea Strait (OHshima '33). Saseho, on ships' bottoms

Miyake '37). Tomioka, Amakusa Is. IkedA '31; BABA '36; Inao '28).

Kagosima Bay (miti' '43).

6. Lepas anserifera LINNÉ

Kyusyu : Tomioka, Amakusa Is ., on a pum:ce-stone (BABA '33). Kazusa, Nagasaki-ken, on cuttle-fish bones (Yamazakı '34). Ryukyu : Daitô-zima, E. of Okinawa Is., on ! uoys (Sugryama '31).

7. Lepas pectinata SPEngler

Tomioka, Amakusa Is., on shells of Janthina, pumice-stones and floating woods BABA '38'.

\section{Family Heteralepadidae NILSSON-CANTELL}

8. Heteralepas (Heteralepas) quadrata (Aurivillius)

Tomioka, Amakusa Is., on Scyllariles haani (INAO '28). Tomioka, on

Plagusia dentipes (HIRAIwa '28; Orishima '29; BABA '39). Tomioka, on

Panulirus japonicus (IKEDA '29; Miyake'42).

9. *Heteralepas (Paratepas) distincta n. sp.

Tomioka, on buccal regions of Panulirus japonicus (IKEDA 5/V '29). 


\section{Family Trilasmatidae NILSSON-CANTELL}

10. Trilasmis (Poecilasma) Kaempferi (DarwIN

Tomioka, Amakusa Is., on Macrocheira kaempferi (OKABE '28).

11. Trilasmis (Temnaspis) amygdalum 'AURIVILIIUS)

Tomioka, Amakusa Is., on mouth-parts of Panulirus japonicus (IKEDA

'29; MIYAKE '42).

\section{Family Chthamalidae DaRwIN}

12. Chthamalus challengeri HoEK

Kyusyu : Mozi; Hakata Bay, Hukuoka-ken (mini'36 . Beppu, Ooita-ken (mini '36) . Aosima, Miyazaki-ken (mihi '36). Okinosima, Korea Strait (Ohshima '33). Tomioka. Amakusa Is. (mihi '43). Kagosima (mihi'43). Yalkusima and Tanegasima (NAKAMUra and ToKuda '33; mihi'43). Ryukyu : Isigaki-zima, Yaéyama Is. (IwASAKI).

13. Chthamalus Pilsbryi Hro

Aosima, Miyazaki-ken (miti '43). Tomioka, Amakusa Is. (mini '43).

Tanegasima (mini'43).

14. *Chthamalus intertextus DARWIN

Genka, west coast of Okinawa-zima (MrYADI '37). Benoki, west coast of

Olinawa-zima (MIYAKE '37).

15. Octomeris sulcata Nilsson-Canteli.

Kyusyu : Tomioka, Amakusa Is. (mini '36). Izumi, Kagosima-ken, on

Balanus tintinnabulum volcano (Kagosima Normal School). Aosima, Miyazaki-ken ( $m i n i$ '43). Tanegasima (mihi'43). Ryukyu: Isigakizima,

Yaéyama Is., on Mitella mitella and Tetraclita squamosa japonica (IWASAKI).

\section{Family Balanidae GRAY}

16. Balanuis tintinnabulum volcano PILSBRY

Kyusyu: Aosima, Miyazaki-ken (mihi '43). Saseho, on ships' bottoms (MiYaKe '37). Izumi, Kagosima-ken (Kagosima Normal School). Yamakawa, Kagosima-ken (HABE '42' . Ryukyu : Isigaki-zima, Yaéyama Is. (IWASAKI).

17. Balanus tintinnabulum rosa PILSBRY 
Kyusyu : Iki-sima, Korea Strait, on bamboo (Tokuda '37). Saseho, on ships' bottoms (MIYAKE '37. Tomioka, Amakusa Is. (IKEDA '31 ; BABA '39; HABE '42). Izumi, Kagosima-ken (Kagosima Normal School). Aosima, Miyazaki-ken (mini '43;. Bungo Channel, on submerged ships (Kyusyu Univ., Zool. Inst.) Ryukyu : Daitô-zima, south of Okinawa Is., on buoys (Sugryama '31). Iriomote-zima, Yaéyama Is. (OHshima '33).

18. Balanus amphitrite communis DARWIN

Tomioka, Amakusa Is. (Murakami '42). Iriomote-zima, Yaéyama Is. (OHs HIma '33).

19. Balanus amphitrite albicostatus PILSBRY

Kyusyu ; Mozi, Hakata Bay, Hukuoka-ken (mihi '36). Okinosima, Korea Strait (Orshrma '33). Beppu, Ooita-ken (mihi'36). Aosima, Miyazakiken (mihi '43). Ariake-kai, Saga-ken, on oyster farms (INuo '42). Misumi, Kumamoto-kè (mihi '36). Tomioka, Amakusa Is. (mihi'36 ; Murakami ' 42 ). Yamakawa, Kagosima-ken (HaBe '42). Ryukyu : Iriomote-zima, Yaéyama Is, NaKamura '33'. Isigaki-zima, Yaéyama Is. (Mryake '37).

20. Balanus amphitrite hawaiiensis BROCH

Saseho, ou ships' bottoms (MiYake '37).

21. Balanus amphilrite krügeri NILsSON-CANTELL

Ariake-kai, Saga-ken, on oyster farms (INuo '4:). Tomioka, Amakusa Is., on submergel plates (MIYAKE '42).

22. Balanus amphitrite cirratus DARWIN

Iki-sima Korea Strat, on bamboo (ToKudA '37). Misumi, Kumamotoken, on shells of a gastropol Rapana thomasiana (mihi '36).

23. Balanus amphitrite poecilotheca KRÜGER

Tomiokil, Amakusa Is., on a hydroid Dendrocoryne sp. (Kawamoto '3 ; HABE '42). Tomioka, on a stem of a gorgonid Acanthogorgia sp. KaWAMOTO '32).

24. Balanus trigonus DaRWIN

Kyusyu : Iki-sima, Korea Strait, on bamboo (Tokuda '37). Okinosima Korea Strait 'OHshima '33. Saseho, on ships' bottoms (MiYake '37). Tomioka, Amakusa Is. 'mihi '43. . Sakura-zima, Kagosima Bay (TokudA an l NaKamura '33). Ryukyu: Daitô-zima, south of Okinawa Is. (SUgryama '31). Iriomote-zima, Yaéyama Is. (OHshima '33).

25. Balanus socialis HoEK

Usibuka, Amakusa Is., on the carapace of Lambrus validus (IKEDA 
32). Tomioka, Amakusa Is., on the carapace of Lambrus validus (BABA

'33). Yamakawa, Kagosima-ken HABE '42).

26. *Balanus cepa DARWiN

Tomioka, Amakusa Is., on a solitary coral Flabellum (TAKENo).

27. *Balanus allium DARWIN

Usibuka, Amakusa Is., on a stem of a coral Dendrophyllia sp. (IKEDA '32).

28. Balanus calceolus DARWIN

Tomioka, Amakusa Is., on a gorgonid Acanthogorgia sp. (OHshima '31;

KAWAMOTо '32).

29. Balanus cymbiformis DARWIN

Tomioka, Amakusa Is., on a gorgonid Melitodes flabellifera (BABA '38).

30. Balanus granulatus Hiro

Tomioka Amakusa Is, on antipatharians (OHshima '31; IKEDA '31;

BABA '32; BABA '33).

31. Acasta pectinipes PILSBry

Tomioka, Amakusa Is., in sponges (BABA '33).

32. *Acasta flexuosa (Nilsson-CANTELL)

Tomioka Amakusa Is, in a sponge (IKEDA '31).

33. Acasta echinata HiRo

Tomioka, Amakusa Is., in the stalk of an alcyonarian Dendronephthya sp. (mihi'36).

34. Creusia spinulosa f. eu-spinulosa BROCH

Takamatu near Tomioka, Amakusa Is., on Goniopora sp. (BABA '31).

35. *Creusia spinulosa f. quarta KOLOSVÁRY

Tomioka, Amakusa Is., on Oulastrea crispata (miki '43).

36. Pyrgoma crenatum SOWERBY

Tomioka, Amakusa Is., on Tridacophyllia lactuea (mihi' 43 ).

37. Telraclita squamosa japonica PILsBry

Kyusyu : Karatu, Saga-ken (mihi '41). Iki-sima. Korea Strait

(Tokuda '37). Aosima, Miyazalki-ken (mihi '43), Tomioka. Amakusa

Is. (mihi '36). Izumi, Kagosima-ken (Kagosima Normal School). Yamakawa, Kagosima-ken (Habe '42). Yakusima (Tokuda and Nakamura '33 .

Tanegasima mihi '43, . Ryukyu : Iriomote-zima, Yaéyama Is. (OHshima '33). Isigaki-zima, Yaéyama Is. (Iw ASAKI!

38. Tetractita squamosa viridis DarwiN

Tanegasima (mini' 43 ).

39. Tetraclita squamosa formosana HrRo 
Tanegasima (miki'43).

40. *Tetraclita (Tetraclitella) chinensis NILSSON-CANTELL

Kyusyu: Aosima, Miyazaki-ken (mihi '43). Okinosima, Korea Strait (Ohshima '33). Tomioka, Amakusa Is. Ineda '32; BABA '38). Yakusima Tokuda an' Nakamura '33). Ryukyu: Isigaki-zima, Yaéyama Is., on Mitella mitella (IwASAKI).

41. Tetraclita (Tetraclitella) darwini PILSBRY

Aosima, Miyazaki-ken (mihi'43). Tomioka, Amakusa Is. (mihi'36).

42. Chelonibia testudinaria (LINNÉ)

Hakata Bay, on the carapace of the loggerheat turtle Caretia olivacea (Kyusyu Univ., Zool. Inst.).

The majority of the cirripels heretofore recorded from Kyusyu and Ryukyu Islands are forms collectel by dredging from deep waters. However, the thirty-three species comprising forty-two different forms, when subspecies and varieties are included, mentione in the present paper are mainly shallowwater cirripeds, occurring commonly in intertidal zones. They thus afford a favourable material for analyzing the faunistic feature of these districts in comparison with that of the neighboring regions.

A comparison of the littoral cirripedian fauna of Kyusyu and Ryukyu Islands with that of the south coast of Honsyu and also with that of Formosa, both explored by myself (HrRo 1937b, 1939), indicates that the cirripedian fauna is rather homogeneous throughout the coast of Japan apparently owing to the influence of the 'Kurosio'. Most of the littoral cirripeds found in this region belong to the Indopacific elements and have wide range of distribution both northward and southward.

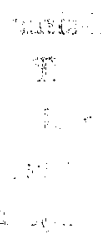


Distribution of the representatives of littoral cirripeds in the region from Japan to Formosa.

\begin{tabular}{|c|c|c|c|c|}
\hline Names of the species & $\begin{array}{l}\text { Southern } \\
\text { Honsyu }\end{array}$ & Kyusyu & $\begin{array}{c}\text { Ryukyu } \\
\text { Islands }\end{array}$ & Formosa \\
\hline Mitella mitella 'LINNÉ) & + & + & + & rare \\
\hline Ibla cumingi DARWIN & + & + & $(+)$ & rare \\
\hline Chthamalus challengeri HoEK & + & + & + & - \\
\hline Ch. pilsbryi HIRo & + & + & $(+)$ & - \\
\hline Ch. intertextus DARWIN & - & - & + & + \\
\hline Ch. malayensis PILSBRY & - & - & $(+)$ & + \\
\hline Ch. moro PILsBry & - & - & $(+)$ & + \\
\hline Octomeris brunnea DARWIN & rare & - & $(+)$ & + \\
\hline Oct. sulcata NILSSON-CANTELL & + & + & + & + \\
\hline Balanus tintin:abulum tintinnabulum $(\mathbf{L}$.) & - & - & - & + \\
\hline Bal. tint. occator DARWIN & - & - & $(+)$ & + \\
\hline Bal. tint. volcano PILsBRY & + & + & + & - \\
\hline Ba!. tint. rosa PILsBRY & + & + & + & + \\
\hline Bal. amphitrite communis DARWIN & + & + & + & + \\
\hline Bal. amph. albicoslatus PILSBRY & + & + & + & + \\
\hline Bal. amph. krügeri NILSSON-CANTELL & + & + & $(+)$ & + \\
\hline Bal. amph. hawaiiensis BRocH & + & + & $(+)$ & + \\
\hline Bal. amph. cirratus DARWIN & + & + & $(+)$ & + \\
\hline Tetraclita squamosa japonica PILSBRY & + & + & + & - \\
\hline Tet. sq. viridis DARWIN & + & + & $(+)$ & + \\
\hline Tet. $s q$. formosana $\mathrm{HIRO}$ & rare & + & $(+)$ & + \\
\hline Tet. chinensis NILSSON-CANTELL & + & + & + & + \\
\hline Tet. darwini PILSBRY & + & + & + & + \\
\hline Tet. divisa NILsSON-CANTELL & - & - & - & + \\
\hline
\end{tabular}

+ common; - absent; (+) probably present, though not included in the present collection.

As listed in the accompanying table, the species belonging to Chthamalus and Oclomeris seem to show rather restricted distribution, as compared with the subspecies of Balanus tintinnabulum, Balanus amphitrite and Tetraclita squamosa. The three species of Chthamalus common in Formosan coasts are unknown in Japan proper, but they probably extend as far as to the Ryukyus. 
Chthamalus challengeri and Ch. pilsbryi, the true Japanese forms, on the other hand, are distributed south to the Ryukyus, but not to Formosa. Octomeris brunnea apparently belongs to the former category, while $O$. sulcata to the latter.

Of Balanus tintinnabulum, B. amphitrite and Tetraclita squamosa most of the subspecies are widely distributed from Japan to Formosa, and show local variation more or less in density. A few, such as $B$. tintinnabulum tintinnabulum, $B$. tint. occator and B. amphitrite cirratus, however, aro more limited in distribution. As a good example of the transition of distributional center we may reckon the three subspecies of Tetractita squamosa (viz. viridis, formosxna and japonica). Subsp. japonica is entirely missing in Formosa, but both viridis and formosana are prevalent. In Japan proper, however, japonica is predominant, and both viridis and formosana are found only along the southern Pacific coast, though the last-named one is very scantily represented at Seto, Wakayama-ken. At Yaku-sima and Tanega-sima islands, south of Kyusyu, viridis is domicant, but both formosana and japonica are rather poorly represented.

Anyhow, the Ryukyu Islands present a mixed feature of the tropical and temperate forms of the littoral cirripedian fauna. It is also evident that a wide gap between Tanega-sima and Amami-ôsima interrupts or controls the extension of distributional range of both the tropical and temperate forms. Thus the 'Watase-Line', recognized by Japanese zoogeographers as limiting the distribution of land animals, seems valid for littoral animals as well.

\section{Some Systematic Accounts \\ Heteralepas (Paralepas) distincta n. sp.}

(Figs. I \& 2c, d)

The present species which seems to be new to science is represented by three large specimens attached to the buccal region of the spiny lobster Panulirus japonicus, together with many small specimens of Heteralepas (Heteralepas) quadrata. So I at first took them to belong to the latter species. Yet they distinctly differ from this in its internal structure.

Capitulum almost globular, a little compressed laterally near orifice, from which a slight dorsal keel runs downwards along carinal side. Orifice provided with puckered lips, small, not protuberant, less than one-fourth as long as capitulum. Integument yellowish in preserved condition, somewhat thick, but not hard; its surface smooth or finely wrinkled transversely, probably owing to the condition of preservation. Scuta apparently absent, leaving the 




Fig. 1. Heteralepas (Paralepas) distincta n. sp. $A$, animal side view $\times 3$; $B$, the same in occludent view $\times 3 ; C$, labrum and palpus $\times 40 ; D$, mandible $\times 50 ; E$, maxilla $\mathrm{I} \times 50 ; F$, maxilla II $\times 40 ; G$, distal part of cirrus $\mathrm{V} \times 60$.

trace of adductor muscle as a white patch below orifice. Peduncle very short, about one-third as long as capitulum, slender, coarsely wrinkled, and sharply defined from capitulum.

Mouth-parts: Labrum with closely-set sharp denticles. Palpus conical, with bristles along inner margin. Mandible with three teeth and a lower angle; all projections comparatively short and prominently pectinated inferiorly. Maxilla I with a notch rather wide for the subgenus Paralepas present below a strong and two smaller upper spines; frontal edge below notch slightly protruded and armed with spines of different sizes, two of which are particularly 
much stouter than others. Maxilla II with a continuous row of short bristles along frontal edge and a sparse set of bristles on proximal end of upper edge.

Internal body very plump, globular, and bears on each side a welldeveloped filamentary appendage about two-thirds as long as cirrus $I$ at base of the latter. Cirri with rather feebly developed rami, composed of a few segments, of subequal length except the first one. Protopodite of each cirrus generally long, much broadened downwards. Both rami not curled, about as long as protopodite. In anterior rami of cirri V and VI, five to eight distal segments provided each with two strong dorsal bristles, a feature typical of the subgenus Paralepas. Caudal appendage 7- or 8 -segmented, slender, a little longer than protopodite of cirrus VI. Numbers of segments in all cirri are as follows :

$$
\overbrace{9{ }_{8}}^{\text {I }} \overbrace{13 \quad 14}^{\text {II }} \overbrace{14}^{\text {III }} \overbrace{15}^{\text {IV }} \overbrace{14}^{\text {V }} \underbrace{\text { VI }}_{14}
$$

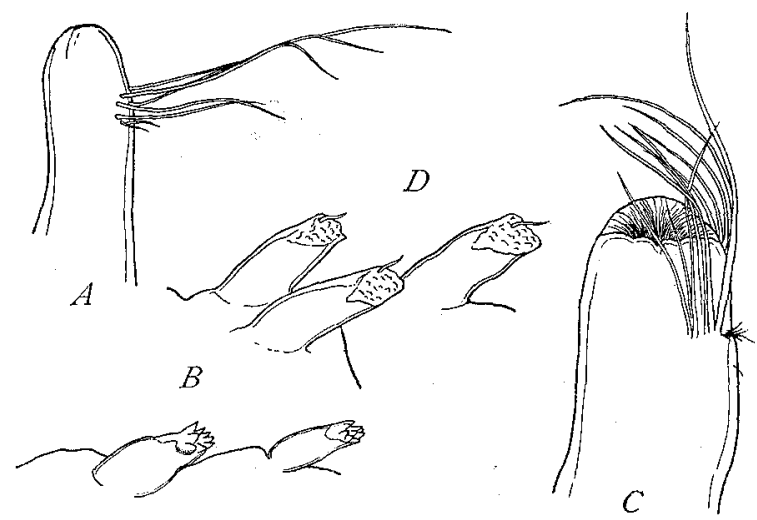

Fig. 2. Heteralepas Heteralepas) quadrata (AUnIvillius) $[A, B]$ and Heteralepas (Paralepas) distincta n. sp. $[C, D] . A, C$, end of penis $\times 100$ (A) $\times 90(C) ; B, D$, rivet-like appendages of penis $\times 300$.

Penis very stout, a little longer than cirrus VI, distinctly annulated and has a peculiar armature. Each ring is beset with a transverse row of rivet-like peculiar appendages, recalling those of Heteralepas (Heteralepas) quadrata (AURIVILLIUS) and $H$. (Paralepas) lithotryae HoEK. The tip of each appendage is somewhat truncated, rugged, and provided with a short sensory hair. In the above two species, the tip is more rugged, being provided with distinct tubercles and 
lacking any hair. Moreover, a few long bristles directed towards the base are scattered all over the surface. The extremity is abruptly tapering, without annulations, and bears two tufts of long bristles distally near the end.

Measurements of largest specimen in $\mathrm{mm}$ : Length of capitulum 11, breadth 11, diameter 8 ; length of peduncle 4.5 , diameter 4 ; length of orifice 2.5 .

\section{Chthamalus intertextus DARWIN}

It is of interest to find that only this species among all the Formosan Chthamalus-species is spread into the Okinawa Islands. This barnacle is characterized by the depressed, extremely corroded walls and by the beautiful violet colour inside the wall. The opercular valves on each side are firmly calcified together, remaining only a trace of suture in the lower half of the interior.

\section{Balanus cepa DARWIN}

For synonymy see Nilsson-Cantell , 1938, p. 52.

Some small dry specimens of Balanus, attached to a solitary deepsea coral Flabellum sp. from Tomioka, agree fairly well with Balanus fujiyama ANNANDALE, which I have described on specimens attached to Pinctada maxima coming from the neighborhood of Port Darwin, N. W. Australia (HIRo, 1936). This species, however, was found as synojymous with Balanus cepa DARWIN by NILssonCANTELl (1938) who examinel ANNANDALE's type specimens of $B$. fujiyama. Brief descriptions based on the present material follow:

Shell steeply conical, distinctly ribbed longitudinally on lower half aud coloured dull reddish-purple on summits of compartments. Orifice small, about $1.2 \mathrm{~mm}$ in diameter, ovate in outline. Radii very narrow, hardly distinguishable, their sutural edges being septate though not strongly. Base flat, with radial lines interiorly.

Scutum finely striated longitudinally; pit for depressor muscle distinct, adductor ridge moderately prominent, artieular ridge evenly arched and long. Tergum with straight scutal margin and pointed apex, though not beaked; externally flat, entirely lazking spur-fasciole; spur broad, as long as one-half its width, its scutal margin being one-half as loag as basal margin and oblique to scutal margin of valve; no crest for depressor muscles.

Measurements in $\mathrm{mm}$ :

$\begin{array}{lrr}\text { Carino-rostral diameter } & 6.5 & 5.5 \\ \text { Height } & 4.2 & 4.0 \\ & & \\ & & \\ & & \end{array}$


This species was first described by DARwIN from Japan, and later recorded by PILSBRY (1916) from Mogi, Nagasaki-ken, not far from the locality of the present specimen.

\section{Balanus allium DARWIN}

(Fig. 3)

Balanus allium, DARWIN, 1854, p. 281; PILSBRY, 1916, p. 228; Broch, 1922, p. 325.

Acasta madreporicola, BRoch. 1922, p. 333.

?Balanus arcuatus, HoEk, 1913, p. $210 ; P_{\text {ILSBRy, }}$ 1916, p. 228 ; Nilsson-Canteld, 1921, p. 337 ; Broch, 1931, p. 78 ; NILSSON-CANETLL, 1938, p. 52.

The specimens found attached to the coral Dendrophyllia taken from Usibuka seem to correspond fairly with Balanus allium DARWIN, especially in the shape of the tergum.

Shell steeply conical, somewhat compressed laterally, coloured pale pinkish purple or white all over, and strongly ribbed longitudinally; the ridges are closely placed to one another, connected with the corresponding ridges over the surface of basal cup, and sometimes transversely striated or beaded. Parietal area of carinal latus extremely narrow, with a single ridge and sometimes obliterated, only leaving behind broad ala and radius, as shown in BROCH's figure of Acasta madreporicola. Rarlii broad, with horizontal summits, and finely striated transversely. Interior of parietes strongly ribbet longitudinally, provided with prominent septate sutural edges. Whole shell sometimes covered entirely or in part by thin calcareous layer originated from the coral, so that all radii may be obliterated.

Base flat or somewhat hollowed out, being partially imbedded in coral, but without forming any regular cup-iike shape; externally furnished with prominent ridges continued from those of compartments, and internally with delicate radial ridges.

Scutum with closely-set, very feebly crenated growth-lines and covered all over by yellowish cuticle which is hairy along growth-lines. Articular ridge very prominent, evenly arched and projecting beyond tergal margin. A deep pit for lateral depressor muscle present. Adductor ridge scarcely definet, though pit for adductor muscle is rather distinct.

Tergum very broad, flat and covered externally with yellowish cuticle, which is hairy along growth-lines as in scutum. Growth-lines smooth, 


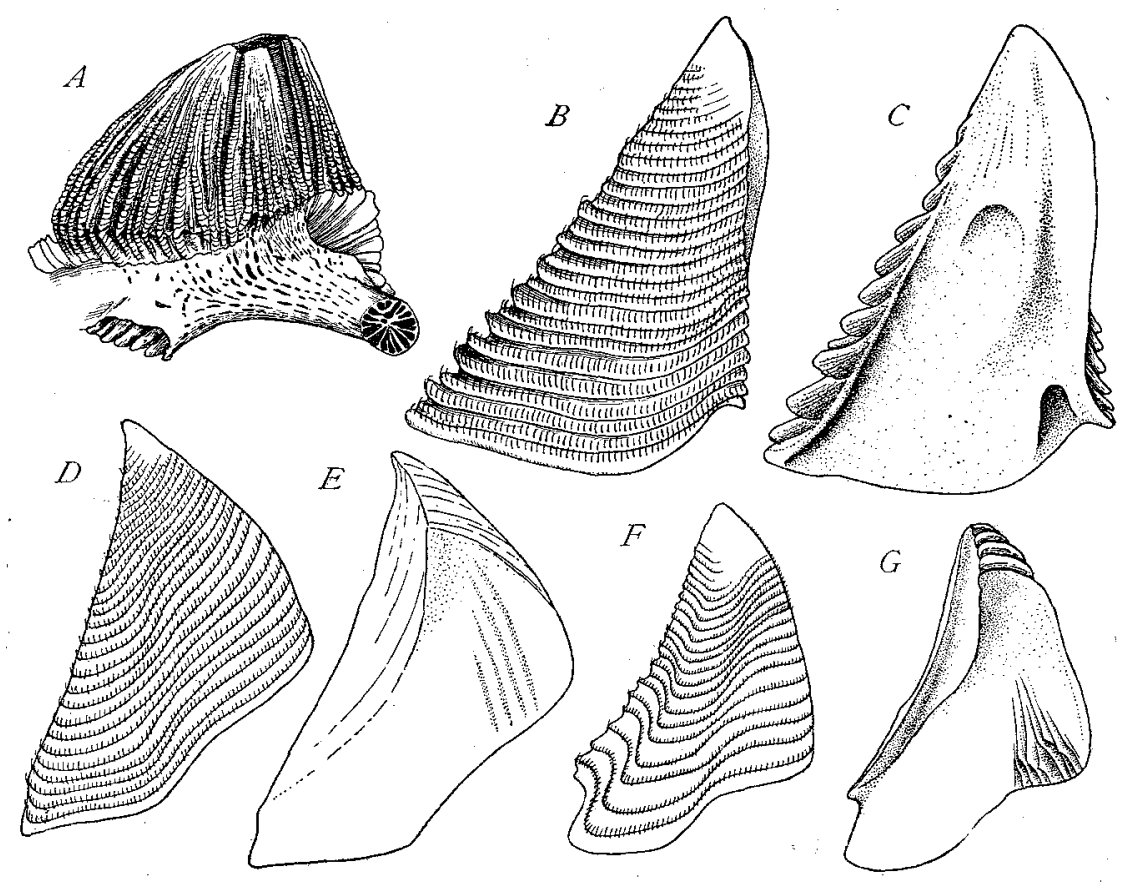

Fig. 3. Balanus allium Darwin. $A$, animal in side view $\times 3 ; B$, outer side of scutum $\times 15 ; C$, inner side of scutum $\times 15 ; D$, outer side of tergum $\times 15 ; E$, inner side of tergum $\times 15 ; F$, outer side of tergum of forma truncatus nov. $\times 8 ; G$, imer side of tergum of forma truncatus nov. $\times 8$.

closely-set. Apex pointed, but not beaked, scutal margin almost straight. Spur about one-half as wide as basal margin, or even a little wider, and very short, less than one-half of its own width; its scutal margin nearly confluent with basiscutal angle of valve. Internally, articular ri'lge very low, articular furrow broar and almost flat; crests for depressor muscles very feeble, and 4 to 6 in number.

The internal parts could not be examined, as the specimens were dried.

Remarks: As clear from the above description and figures, the present specimens seem to be typical for this species. Several specimens on Dendrophyllia micranthus from Tanabe Bay, middle Honsyu, also agree with DaRwin's original description, and I have no doubt that they belong to the same species. 
The closely allied species, Balanus arcuatus, according to HoEk (1913), is distinct from $B$. allium in the peculiarity of the arcuated shape of the tergum. As to the affinity of Acasta madreporicola baving a broad spur, BROCH (1931) considers it to be "only an extreme variant of $B$. arcualus determined by special biological conditions". On comparison with his figure, however, Acasta madreporicola appears to be more like $B$. arcuatus, as its tergum is very broad, and not so beaked at the apex.

Forma truncatus (nov.) - A lot of specimens on Dendrophyllia arbuscula from Tanabe Bay before me contain an unique example having the following peculiarities:- The external appearance of the shell and scutum agrees very well with the above description for the typical form of $B$. allium. The tergum, however, is peculiar in showing growth-lines rather more widely separated from one another and a less-pointer apex. The spur is distinctly defined from the basal margin of the valve, as it is about one-half as wide as the basal margin, a little longer than one-half of its own width and bas a truncated end; its scutal margin is quite separate from the basiscutal angle and parallel with the almost straight scutal margin of the valve. Crests for the depressor muscles are very prominent and more numerous than in the typical form. It measures about $12 \mathrm{~mm}$ in carino-rostral diameter and $5 \mathrm{~mm}$ in height.

It is probable that the shape of the tergum is highly variable in this species, and thus of little use for specific differentiation. Balanus arcuatus Hoek may well be regarded as an extreme variant or subspecies of $B$. allium, not as a separate species. HoEK (1913 and PILSBRy (1916) also have expressed their doubt as to the validity of the species. Likewise, the validity of $B$. fujiyamaformis recently described by KolosváRY (1947b) from Singapore may be questioned. This form is appareutly more akin to $B$. allium $\mathrm{f}$. truncatus than to $B$. fujiyama which is synonymous with $B$. cepa.

\section{Acasta flexuosa (NILSSON-CANTELL)}

This sponge-inhabiting barnacle was first described by me (HrRo 1931) from Amakusa under the name of Acasta amakusana n. sp. Later, however, it was found as synonymous with Pseudoacasta (?) flexuosa Nilsson-Cantell (1931) described a few months before from an unknown locality of Japan. The structure of the specimens from Amakusa agrees with my full description based on the specimens from Seto (Hiro 1937b), so that there is nothing to be added to it.

\section{Acasta echinata HIRO}

(Figs. 4 \& 5)

This species was first deseribed by me on specimens imbedded in the 
stalk tissue of an alcyonarian Dendronephthya collected at Tomioka, Kyusyu (HIro 1937a). Very recently, BRoch (1947) rediscovered it at Condor Is., Indochinese coast, and described in details, so that no further comment seems necessary. He mentions some differences between his specimens and mine; but all of the alleged differences seem to me of little systematic value.

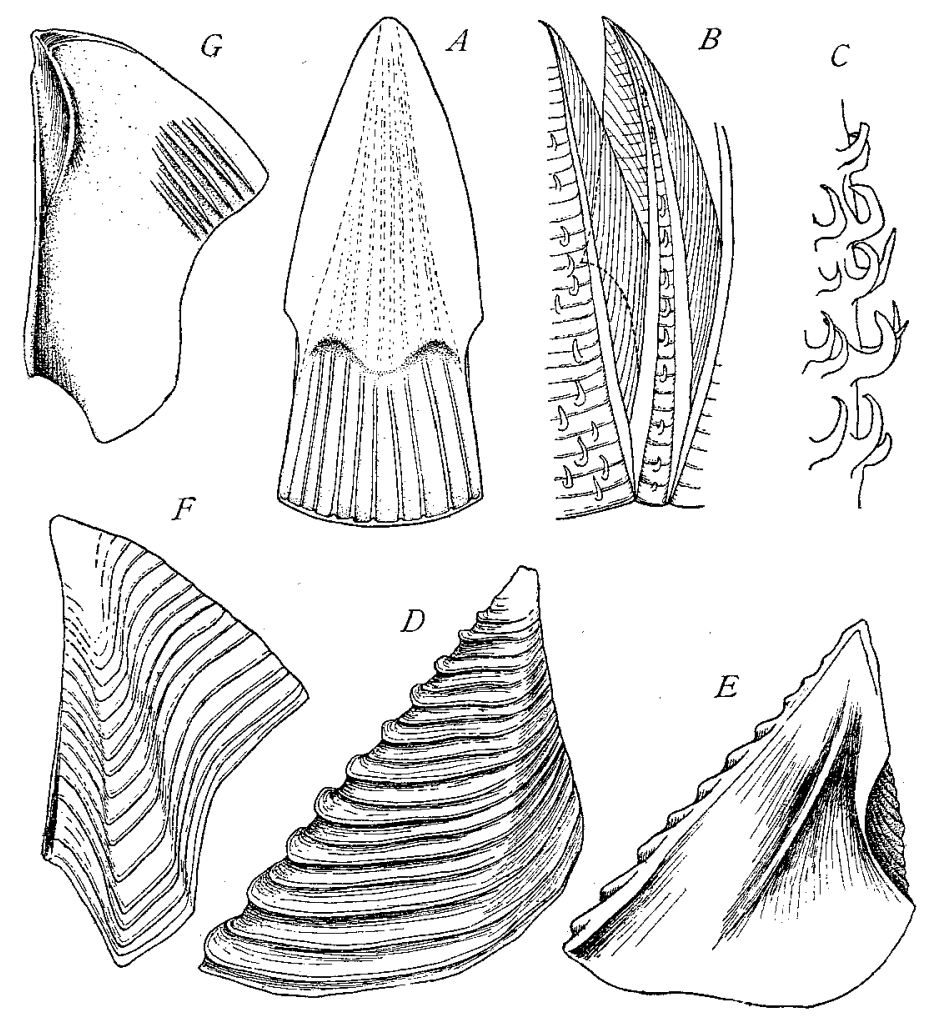

Fig. 4 Acasta echinata HiRo. $A$, inner side of carina $\times 5 ; B$, outer side of carinolateral compartment and its neighbourings $\times 5 ; C$, hook-like spines on compartments $\times 15, D$, outer side of scutum $\times 8$; $E$, inner side of scutum (from other specimen) $\times 8, F$, onter side of tergum $\times 8 ; G$, inner side of tergum $\times 8$

The scutum is usually a little wider than high, but sometimes as wide as high, as shown in Fig. 4E. Likewise, the scrlpture of the inner side of the opercular valves is, as he noticed, subject to rather considerable variation, the 
adductor ridge and crests or pits for depressor muscles being either distinct or faint in different specimens. The same is also true for the mouth-parts and cirri.

Of the mouth-parts, the labrum has a minute tooth on each side of the median deep notch, but it may be missing. Mandible has always five teeth but its fourth tooth is usually bifid as in the second to third, and sometimes obtusely pointed.



Fig. 5. Acasta echinala Hiro. $A$, lower segments of anterior ramus of cirrus IV $\times 40 ; B$, labrum $\times 40 ; C$, palpus $\times 40 ; D$, mandible $\times 40$; $E$, maxilla II $\times 40 ; F$, maxilla $I \times 40$.

In cirri I-III, the anterior ramus is longer than the posterior. In the remaining posterior cirri, the rami are subequal in length and bear 2 or 3 ventral bristles on each segment. In cirrus IV, the lower half of the anterior ramus bears 1 or 2 hook-like teeth on each segment and the distal half of the posterior ramus has only one tooth. The numbers of segments in the cirri are as follows: 


$$
\overbrace{15}^{I} \overbrace{10}^{I I} \overbrace{12}^{I I} \frac{I I}{I V} \overbrace{12}^{I V} \overbrace{?}^{V} \overbrace{?}^{\text {VI }}
$$

Penis is finely annulated all over and about twice as long as cirrus VI; no basidorsal point is present.

Measurements in $\mathrm{mm}$ :

$\begin{array}{lrr}\text { Carino-rostral diameter } & 7 & 6.5 \\ \text { Height } & 11 & 10\end{array}$

\section{Creusia spinulosa f. quarta KoLOSVÁRY}

(Fig. 6)

Creusia spinulosa var. 4, DARWIN, 1854, p. 378.

Creusia spinulosa forma quarta, KolOSVARY, 1947a, p. 426.

Shell flat, with many prominent radiating ridges: base somewhat cylindric. Scutum not much elongated transversely, basal margin being a little longer than tergal margin; basitergal corner evenly curved, articular ridge long and rather high, adductor ridge prominent, not extending down to the base. Tergum similar to DARWIN's Pl. XIV, Fig. 6i ; spur well definëd from basal margin of valve, square in outline, being about as high as broad, and about one-third as broad as basal margin of valve; spur-fasciole distinct.

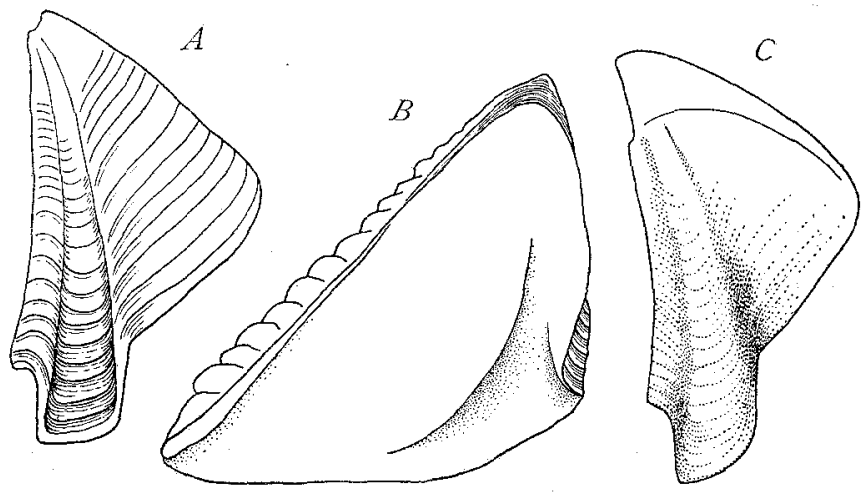

Fig. 6. Creusia spinulosa f. quarta KOfOSÁRY. $A$, outer side of tergum $\times 20 ; B$, inner side of scutum $\times 20 ; C$, inner side of tergum $\times 20$. 
According to Darwin, the shape of the tergum is highly variable, the spur being sometimes more or less narrow and pointed, and thus prolucing a closed spur-furrow. However, I have not met with such an extreme variant.

\section{Tetraclita (Tetraclitella) chinensis NiLsson-CANTEI.L.}

Tetrüclita purpurascens ehinensis, Nilsson-Canteld, 1921, p. 359; Hiro, 1939, p. 273.

Tetraclita purpurascens nipponensis, HIRO, 1931, p. 155 ; HrRo, 1937b, p. 469.

As I have mentioned on the specimens from Formosa (Hrro 1939), this cirripel is characterized by the six large apertures formed on the wall, two apertures in carina and rostrum and one in lateral compartments*. Such perforated state is very common in older specimens, though not found in small or younger ones. The shell is generally dusky white owing to its hypobiotic habitat, and provided with a few or numerous prominent radial ridges.

Through the courtesy of Dr. Melbourne WARD who was in charge of the Australian Museum at Sydney, I have been able to examine Australian specimens of the typical Tetraclita purpurascens (Wood) and compared them with the Oriental specimens. The Australian purpurascens has no indication of such apertures. Furthermore, the shell is rather thicker and attains to a larger size, measuring about $25 \mathrm{~mm}$ in diameter, and its surface is purplish in colour and deeply eroded or granulated, The Oriental form, on the contrary, is pale in colour and smaller in size, not growing over $15 \mathrm{~mm}$ in diameter. More interesting and significant is the ecological evidence that the Oriental form is usually found attached to the underside of stones or to Mitella mitella and other littoral barnacles or shells, and when such stores are accidentally overturned, the barnacles attached to the undersicle are apt to suffer death.

The opercular valves are not much different from those in the Australian form. However, the scutum has a longitudinal medial furrow on the outer surface, and the basal margin is hollowed out at the end of the furrow. On these grounds, it seems better to regard the Oriental form as a separate species, distinct from the Australian form which is the type of Tetraclita purpurascens.

* A wrong number of apertures formed on the wall is given in my previous paper (HIRO 1939, p. 274). 


\section{Literature}

ANNANDale. N. 1924. Cirripeles assoziated with Indian corals of the families Astraeidae and Fungidae, Mem. Ind. Mus., vol. 8, no. 1.

Broch, Hj. 1922. Papers from Dr. Th. Morrensen's Pacific Expedition 1914-16, X. Studies on Pacific cirripels. Vidensk. Meld. Dansk naturh. Foren., $\mathrm{Bd} .73$.

-1931. Ditto LVI. Indomalaya Cirripetia Ibid., Bd. 91.

-1947. Cirripeies from Indochinese shallow-waters. Avh. Norske Vidensk.Aka . Oslo, Mat.-Nat. Kl. , 1947, no. 7.

DARwIN, Ch. 1854. A monograph on the sub-class Cirripetia. II. The Balanidae, Verrucidae etc. London.

Hiro, F. 1931. Notes on some new Cirripedia from Japan. Mem. Coll. Sci. Kyoto Imp. Univ., Ser. B, vol. 7, no. 3.

-1936. Report on the Cirripetia collectel in the Malayan waters by the ship 'Zuiho-maru'. Jap. Jour. Zool., vol. 6, no. 4.

-1937a. A new barnacle, Acasta echinata n. sp., imbetded in the stalk of an alcyonarian from southern Japan. Zool. Mag. (Tokyo), vol. 49, no. 2.

- 1937b. Studies on the Cirripedian fauna of Japan. II. Cirripeds found in the vicinity of the Seto Marine Biological Laboratary. Mem. Coll. Sci. Kyoto Imp. Univ., Ser. B, rol. 12, no. 3.

-1939. Ditto IV. Cirripeds of Formosa (Taiwan), with some geographical and ecological remarks on the littoral forms. Ibid., vol. 15, no, 2.

HoEx, P. P. C. 1913. The Cirripedia of the Siboga-Expedition. B. Cirripedia Sessilia. Siboga-Expeditie, mon. 31 .

Kolosváry, G. 1947a. A study of cirripetes associated with corals in the collection of the Hungarian National Museum, Budapest. Proc. Zool. Soc. London, vol. 117, pt. 243.

-1947b. New data of cirripeds a sociated with corals. Ann. Mag. Nat. Hist., Ser. 11, vol. 14.

Nirsson-Cantell, C. -A. 1921. Cirripeden-Studien. Zur Keuntnis dèr Biologie, Anatomie und Systematik dieser Gruppe. Zool. Bidr. Uppsala. Bd. 7.

-1938. Cirripedes from the Indian Ocean in the collection of the Indian Museum, Calcutta. Mem. Ind. Mus., vol. 13, pt. 1.

PIlsbry, H. A. 1916. The sessile barnacles (Cirripe lia) contained in the collections of the U. S. National Museum; including a monograph of the American species. U. S. Nat. Mus., Bull. 103. 